\title{
ANALYSIS OF THE IMPACT OF ELIMINATION EIGHT MAJOR LOSSES IN CO-GENERATION POWER PLANT TO INCREASE PROFITS IN THE PULP \& PAPER MILLS MANUFACTURING INDUSTRY
}

\author{
Muhammad Ayip Fathani ${ }^{1}$, Erry Rimawan ${ }^{2}$, Antonius Setyadi $^{3}$, Bambang Setiawan $^{4}$ \\ Mercubuana University, Jakarta, Indonesia
}

\begin{abstract}
In the industrialized world, increasing productivity and profitability is very important for companies as a benchmark of success in business processes. Some literature has defined the success factor of the successful application of the concept of TPM as a tool to improve the productivity performance of the company, therefore improving the productivity performance of the company becomes the main thing in improving long-term sustainable profitability for the company .

In the manufacturing industry pulp and paper mills, the contribution of the highest production costs is in raw materials (Pulp and chemical raw materials), followed by energy and packaging. The energy sector occupies the top three in the cost contributor to variable costs, it is triggered because in the pulp paper industry sector, the consumption value for electrical energy and heat is very high. Therefore, success in eliminating eight major losses is a major success factor in improving the profitability of the company.

To analyze the effects of elimination of eight major losses, reduction of production costs and increase in profitability can be solved by evaluating the influence of all indicators of eight major losses using PLS-SEM. The data used is operational data co-generation plant production of PT. XYZ in 2019.

From the research conducted it is known that the variable Overall Plant Effectiveness (OPE) is significantly influenced by 2 (two) of the 3 (three) constituent indicators, namely Availability and Performance, both indicators affect: Productivity Improvement, Decreased Production Costs and Increased Profitability of the Company. The priority of improvement that must be done by considering the production cost performance data from the review of variable costs of energy is elimination: Loss Shutdown losses (A1), Loss Production adjustment loss (A2), Equipment failure (A3), Process failure ( A4), Normal Production (A5), and abnormal production (A6).
\end{abstract}

Keywords: Eight major losses, TPM in industry process, SEM-PLS, OPE, Profitability.

Article Received: 10 August 2020, Revised: 25 October 2020, Accepted: 18 November 2020

\section{Introduction}

The Directorate General of Agro and Chemicals noted that in 2009, Indonesia's paper consumption is $29 \mathrm{Kg}$ per $\mathrm{kg} /$ capita / year, and continues to rise by 32.6 per capita in 2013 , and the world's paper needs reach around 394 million tons in that year, the Director General of the Agro Industry Department predicts that the growth of the world's paper needs will grow by an average of 2.1 percent per year, so that the world's paper needs in 2020 are predicted to reach 490 million tons. This makes the government continue to strive to increase the national pulp production capacity to 10.53 million tons in 2017 , and one of them is by expanding the construction of pulp mills and diversification of derivative products.

The Research \& development Agency of the Ministry of Industry stated that in 2013, Indonesia has had 4 pulp industries and 73 paper industries, and 5 integrated pulp \& paper industries with an installed capacity of 18.96 million tons \& amp; realization of pulp and paper production of 4.55 million tons and 7.98 million tons of paper, respectively. (Ministry of Industry Pusdatin, 2019)

Bureau of Management Institute, Faculty of Economics, University of Indonesia revealed that one of the challenges of pulp \& paper industry in industry competitiveness is to have a strategy based on cost efficiency, high productivity, and strategic raw material ownership. These three aspects can deliver the success of the pulp and paper mills industry on an ongoing basis.(ANALYSIS OF THE WORLD PULP AND PAPER INDUSTRY: Input for SOE Managers at the LM FEUI Research Bureau Despite Work Practicesn, 2009)

Aspects of cost efficiency in the pulp \& paper mills industry can not be separated from the cost of goods manufacturing (COGM) components consisting of fixed and variable cost: 


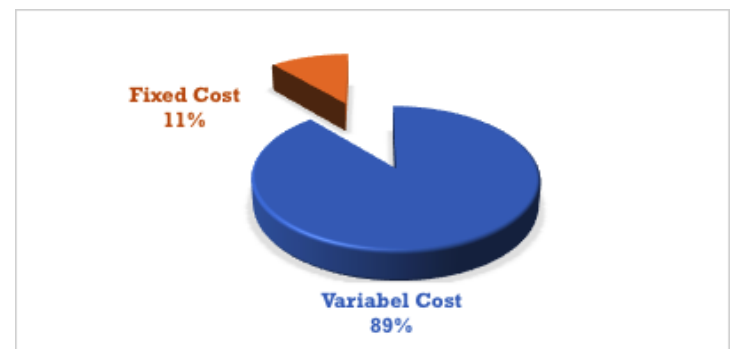

Figure 1.1 cost of goods manufacturing distribution Source: PT.XYZ COGM data

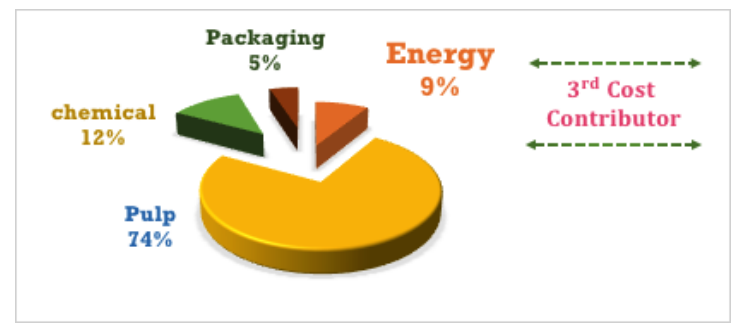

Figure 1.2 variable cost contributorSource: PT.XYZ COGM data

In the paper industry, the highest contribution of production costs is in raw materials (pulp and chemical raw materials), followed by energy and packaging. The energy sector occupies the top three in the cost contributor to variable costs, it is triggered because in the pulp paper industry the consumption value for electricity and heat is very high.(Gambini et al., 2019)

according to (Sugiyono, 2015), according to (Sugiyono, 2015), Overall energy consumption in the industrial sector reached $33 \%$ of total national energy consumption or reached 300 million barrels of oil equivalent (BSM) in 2007. Of these, about $6.5 \%$ or about 19 million BSM is used for the pulp and paper industry. The process flow in the industry is divided into four groups, namely: chemical and thermochemical pulp, mechanical pulp, paper production, and recycled paper, which in each process requires energy derived from fuel (coal, gas and electricity). Fuel is used as a steam generator, while electrical energy is used for electric motors and production machinery equipment. Cogeneration technology is one of the energy-efficient technologies that can be applied in the pulp and paper industry to produce energy (steam and electricity) simultaneously.

according to (Nayak et al., 2013), in the modern manufactur industry, machinery and technology are the driving factors in the business whose availability is functioned as one of the company's strategies in facing market supply, therefore the performance of the machine must be considered because it has a role in the company towards world class manufacturing. Boilers are one of the supporting machines of co-generation combination technology to produce steam and steam turbine generator drives in order to generate electrical energy, the performance is a supporter of cost reduction in energy generation in the pulp \& paper industry, because it can reduce low production costs in manufacturing.

according to (Suzuki, 2017) Overall plant effectiveness (OPE) is a measurement indicator of complex engine performance in the industry process that can maximize production effectiveness and minimize process failure, defects and losses, all of which can be affected by three factors, namely : availability, performance and quality.
(Mardono et al., 2019), explained that efforts in eliminating six big losses and evaluating OEE (overall plant effectiveness) in world class manufacturing standards have been effectively carried out as an improvement in machine performance and provide quality product results, low financing, and provide sustainable profitability impact.

\section{Literature Study}

Co-Genration system, Energy Cost of COGM, Profitability \& Benefit to industry \& TPM.

\subsection{Co-Generation}

Co-generation is an energy-efficient technique because it comes as an efficient way to utilize limited energy resources, and can utilize the same fuel to produce two different energy outputs, namely electrical energy and thermal energy. In the process industry, co-generation can be raised by several sources of energy generation, such as: gas turbines, steam turbines and combined cycle cogeneration options to evaluate energy savings and economic benefits.(Shabbir et al., 2016)

\subsection{Configuration of co-generation steam turbine} In the Co-generation system of steam turbines as shown in Figure 2.1, super heated steam is generated directly through the combustion of fueled boilers (coal, rice husks, or gas). Steam generated by the boiler will be continued to rotate the turbines to move the generator to generate electrical energy. While the saturated steam from the steam turbine, is extracted to become medium pressure steam and low pressure steam, the hot steam is reused for paper manufacturing needs.(Shabbir et al., 2016)

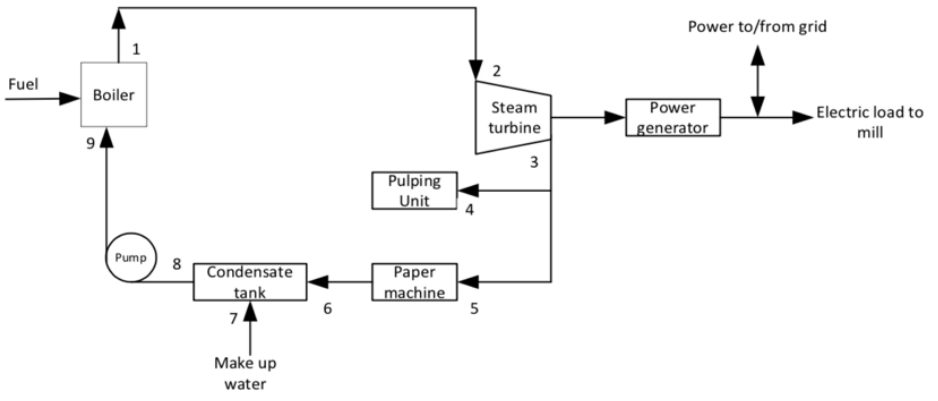

Figure 2.1 schematic diagram of a steam turbine co-generation system (Shabbir et all, 2016)

\subsection{Combined configuration of co-generation steam turbines \& gas turbines}

In the combined co-generation configuration system between steam turbines \& gas turbines, both are used for energy generation. And if the starting fuel in the turbine gas used is rice husks, then it can be converted into syn gas in the gasifier \& amp; combustion in the chamber to be passed on to the gas turbine as an electric energy generation by the generator. Exhaust gas flow in gas turbines, used by Heat Recovery Steam Generator (HRSG) for steam generators with additional fuel combustion. the difference in the combined process cycle is, the steam produced by HRSG is superheated steam that is reused as a steam turbine drive to move the generator to generate electrical energy, then saturated steam that leaves the steam turbine in extraction into Low \&(Shabbir \& Mirzaeian, 2016) 


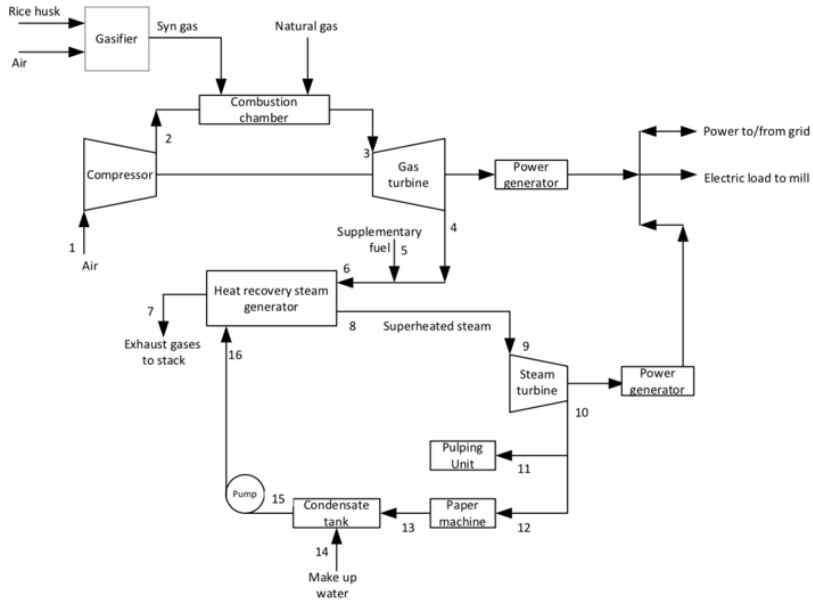

Figure 2.2 Schematic diagram of a steam \& gas turbine co-generation system

(Shabbir et all, 2016)

\subsection{Boilers}

Boiler is a vessel / boiler covered containing water, which in the process the vessel is heated with a furnace / fuel chamber to a certain pressure \& degree of temperature using a variety of fuels (coal, fuel, gas, nuclear and others) to produce water vapor, which will be used for heating and power. Boilers became an important part of the invention of steam engines, because as a trigger for the birth of the evolution of the industry. The existence of boilers in the process industry becomes the most important thing, because disruptions and failure operations caused by external and internal factors will cause a huge loss of energy cost increase and affect the production process, because of its end-toend user nature in the process cycle of the process industry.(Putra \& Purba, 2018)

\subsection{Energy Cost of Goods manufacturing}

Energy cost is defined as the cost incurred to produce an energy per unit of the specified parameter. In energy generation in the co-generation, there are two energy outputs produced, namely electrical energy (Kilowatt) which is used to move production machines and steam (Ton) as the main energy in the paper drying process and as a support in chemical processes .

According to (Bierer \& Götze, 2012), energy costs a lot of costs incurred by the consumption of goods and services for internal energy supply-demand. Cost of goods manufacturing (COGM) is defined as the Cost of Production (HPP) consisting of fixed \& variable cost (Raw material cost, Labor \& Overhead), Where all elements have been added and this price will then be the selling price.

\subsection{Profitability \& Benefit to Industry}

According to (Singgih, 2006), Profitability is defined as the ability of a company to make a profit in the context of its correlation with sales. Whereas according to (Heyzer, 2001), Profitability can be obtained by improving quality, improving productivity and cost reduction. reduction.

(Sudana, 2011), revealed Profitability as the ability of the company to generate profit by using owned resources such as assets, capital or sales of the company, in this context, cost reduction improvement can be used as a reference as profitability generated through low cost advantage in productivity.
2.6 Concept of TPM implementation in process industry According to (Suzuki, 1994), explaining the concept of TPM implementation in the industry process:

1. Identify and eliminate eight major losses in the industry process

2. Minimizing equipment failure in the process industry

3. Implementation of autonomous maintenance program design (AM) in the process industry

4. Perform a planned maintenance program (PM) \& build quality maintenance $(\mathrm{QM})$

5. Improving work competencies for employees

6. Build a work safety culture to eliminate work accidents

\subsection{Overall Plant effectiveness (OPE) Measurement}

In the industry process, products produced in the equipment factory complex because it consists of several interconnected processes, such as compressors, pumps, tanks, heat exchangers, all of which are connected to pipes and instrumentation systems. As a result of integration, it is important to focus on maximizing the overall effectiveness of the plant rather than each individually related equipment. (Suzuki, 1994)

\subsection{Losses Structure}

To distinguish $\&$ measure losses that inhibit the effectiveness of the performance of an engine, it can be done calculation formulations that help Overall Plant Effectiveness (OPE) measurement analysis as shown in figure 2.3 follows:

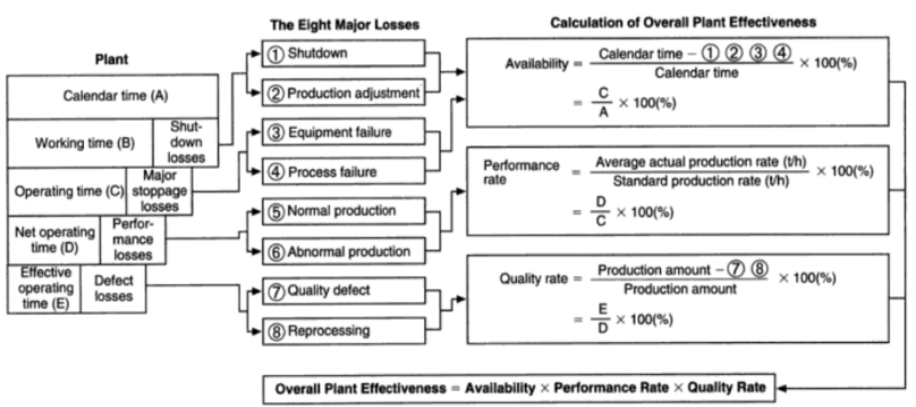

Figure 2.4 losses Structure \& OPESource:

(Suzuki, 1994)

\subsection{Eight major losses}

According to (Suzuki, 1994), suggesting that in every performance of an equipment or engine, of course there are losses that occur in its operation, especially in the process industry because the system is integrated between the equipment, it is described into eight main. disadvantages of equipment or machinery in the process industry include: 
Table 2.1 Eight major losses type

\begin{tabular}{|c|c|c|c|}
\hline Losses Type & Definition & units & Example \\
\hline $\begin{array}{l}\text { 1. Shutdown } \\
\text { Losses }\end{array}$ & $\begin{array}{l}\text { Lost time when production stops } \\
\text { for shutdown maintenance as well } \\
\text { as planned annual periodic repairs }\end{array}$ & days & $\begin{array}{l}\text { Shutdown work, } \\
\text { autonomous inspections, } \\
\text { general repair work, } \\
\text { periodic servicing, dll }\end{array}$ \\
\hline $\begin{array}{l}\text { 2. Production } \\
\text { adjustment } \\
\text { loss }\end{array}$ & $\begin{array}{l}\text { Time lost due to changes in supply } \\
\text { and demand resulting in changes } \\
\text { in production plans }\end{array}$ & days & $\begin{array}{l}\text { Production-adjustment } \\
\text { shutdown, inventqPY } \\
\text { reduction shutdown, dll }\end{array}$ \\
\hline $\begin{array}{l}\text { 3. Equipment } \\
\text { failure loss }\end{array}$ & $\begin{array}{l}\text { Loss of production processing } \\
\text { time, due to sudden malfunction }\end{array}$ & Hours & $\begin{array}{l}\text { Failure of operation sirte } \\
\text { pumps, burning electiinfo } \\
\text { motors, damage to } \\
\text { bearings and shafts, etc. }\end{array}$ \\
\hline 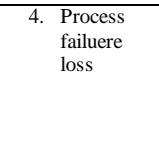 & $\begin{array}{l}\text { Loss of time in the shutdown due } \\
\text { to external factors, such as: } \\
\text { chemical changes or changes in } \\
\text { other physical property materials } \\
\text { that are still in process, damaged } \\
\text { raw materials, operations error }\end{array}$ & Hours & $\begin{array}{l}\text { Leakage, spillage from } \\
\text { process media, scattered } \\
\text { dust, corrosive, erosive, } \\
\text { or operating errors }\end{array}$ \\
\hline $\begin{array}{l}\text { 5. } \text { Normal } \\
\text { production } \\
\text { loss }\end{array}$ & $\begin{array}{l}\text { Loss of production time at the time } \\
\text { of factory start up, shutdown and } \\
\text { change over. }\end{array}$ & $\begin{array}{l}\text { Rate } \\
\text { decrease, } \\
\text { Hous }\end{array}$ & $\begin{array}{l}\text { Reduction of production } \\
\text { rate during machine } \\
\text { heating period after } \\
\text { startup, peridode cooling } \\
\text { down before shutdown, } \\
\text { and product changeover }\end{array}$ \\
\hline $\begin{array}{l}\text { 6. Abnormal } \\
\text { production } \\
\text { loss }\end{array}$ & $\begin{array}{l}\text { Losses that occur when the plant } \\
\text { performs poorly due to } \\
\text { malfunction and abnormal } \\
\text { conditions occur }\end{array}$ & $\begin{array}{l}\text { Rate } \\
\text { decrease, }\end{array}$ & $\begin{array}{lr}\text { Low-load } & \text { operation, } \\
\text { low-speed operation and } \\
\text { operation } & \text { below } \\
\text { production } & \text { standard } \\
\text { values } & \\
\end{array}$ \\
\hline $\begin{array}{l}\text { 7. Quality } \\
\text { defect loss }\end{array}$ & $\begin{array}{l}\text { Losses due to producing defective } \\
\text { products, physical loss of rejected } \\
\text { products, cost losses due to } \\
\text { producing a decrease in product } \\
\text { quality }\end{array}$ & $\begin{array}{l}\text { Hours, } \\
\text { tons, } \\
\text { dollar } \\
\text { /rupiah }\end{array}$ & $\begin{array}{l}\text { Physical loss and time } \\
\text { due to producing goods } \\
\text { that do not match the } \\
\text { quality and quality } \\
\text { standards specified }\end{array}$ \\
\hline $\begin{array}{ll}\text { 8. } & \text { Re- } \\
\text { processing } \\
\text { loss }\end{array}$ & $\begin{array}{l}\text { Recycling losses, due to the } \\
\text { processing of product-making } \\
\text { materials re-cycled into the } \\
\text { processing system }\end{array}$ & $\begin{array}{l}\text { Hours, } \\
\text { tons, } \\
\text { dollar } \\
\text { /rupiah }\end{array}$ & $\begin{array}{l}\text { recycle inappropriate } \\
\text { products from the final } \\
\text { process to the initial } \\
\text { process in order to be } \\
\text { accepted }\end{array}$ \\
\hline
\end{tabular}

2.10 Partial Least Square - Structural Equation Modeling According to (Leguina, 2015), Structural Equation Modeling (SEM) is a multivariate data analysis method used in solving problems for latent variables that cannot be calculated and difficult to measure.

\subsection{1 analysis of the effects of the elimination of eight major losses and the wording on the profitability of pulp \& paper mills manufacturing companies}

According to (Hair et al., 2014), n SEM, there are two approaches:

1. The first approach is broadly applied covariance-based SEM (CB-SEM). in the field of social sciences, and is still a much-preferred method of data analysis in confirming or rejecting theory through hypothesis testing, especially when the sample size is large, the data is usually distributed, and most important, the model is determined correctly . That is, the corresponding variables are selected and linked together in the process of turning the theory into a model of structural equations

PLS handles all types of data, from nonmetric to metric, with very minimal assumptions about data characteristics, reflective and formative constructions and all recursive models identified. However, many industry practitioners and researchers note that, in fact, it is often difficult to find data sets that meet these requirements. Furthermore, the purpose of research can be explored, where we know very little about the relationships that exist between variables. In this case, researchers may consider PLS.

2. Then the second approach is Partial Least Squares (PLS) which focuses on variance analysis and can be done using PLS-Graph, Visual PLS, Smart PLS, and Warp PLS. PLS is a soft model approach to SEM without assumptions about data distribution. PLS is useful for modeling structural equations including formative indicators in applied research projects, especially when participants are limited and the distribution of data is skewed

S-SEM has been widely implemented in various fields of ience, such as behavioral sciences, marketing, organization, ormation systems management, and business strategy.

\section{Methodology}

Based on the literature studies presented, a research model is proposed where 3 OPE variables (X1) are Availability indicators (A1234), performance indicators (A56) and Quality indicators (A78). The three indicators consist of Eight major Losses, namely: Shut down losses, Production Adjustment, Equipment Failure loss (Breakdown), Process failure loss, Normal Production loss, Abnormal Production loss, Quality (defect loss), and Re-Processing loss that affects productivity (Y1) with boiler Production Volume (B1), Decrease in production costs / energy costs (Y2) with indicators (B2) and (B3) and the performance of profitability of the company in the co-generation Plant (Y3) with Budgeting (B4) and actual achievement indicators (B5), Decrease in Energy Cost total consumption (Y4) with indicators (C1) and (C2), Energy Cost total Pulp \&

shown in figure 3.1. The research hypothesis states that there are important factors that can affect the effectiveness of production operations, namely the productivity performance of the co-generation plant that will affect the parameters of each item variable Energy cost and profitability performance of the company. In that view, the research hypothesis is as follows:

- H1: OPE will have a positive impact on boiler plant productivity performance

$\mathrm{H} 2$ : Boiler plant productivity will have a positive impact on co-generation plant productivity performance to reduce energy production costs to energy productivity raw materials - H3: Productivity will have a positive impact to reduce costs.

- H4: Plant productivity performance will have a positive impact to reduce losses and reduce costs

- H5: Lower total costs will have a positive impact on the company's

performance

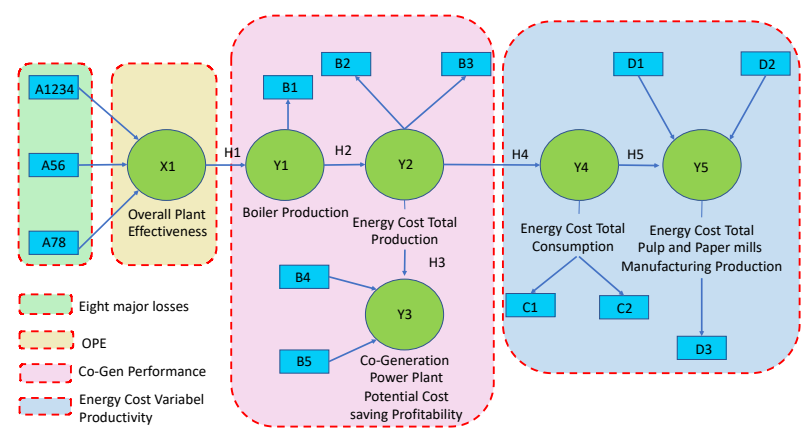

Figure 3.1 SEM PLS modeling framework

Data collected from the operational performance of Pulp \& Paper mills at PT. XYZ for 1 year throughout 2019, and will be tested using SmartPLS 3.0 to evaluate the reliability and validity of research models and assess research hypotheses. 


\section{RESULTS}

4.1. Evaluation of Measurement Reflective Model (Outer Model)

based on the validity of the discriminant, there are several tests that must be done in order for the model to be valid convergently:

- $\quad$ Testing The initial value of outer loading $>0.7$

Table 4.1 testing of reflective outer loading models

\begin{tabular}{|l|l|l|l|l|l|l|}
\hline & X1 & Y1 & Y2 & Y3 & Y4 & Y5 \\
\hline A1234 & 0.963 & & & & & \\
\hline A78 & 0.958 & & & & & \\
\hline B1 & & 1.000 & & & & \\
\hline B3 & & & 1.000 & & & \\
\hline B5 & & & & 1.000 & & \\
\hline C2 & & & & & 1.000 & \\
\hline D1 & & & & & & 0.811 \\
\hline D3 & & & & & & 0.964 \\
\hline
\end{tabular}

stated there are some items or indicators that are not valid convergent validity, outer loading value $<0.7$, then the indicator can be removed from the model.

- $\quad$ Testing the validity of discriminants using heteroite monotrait values (HTMT) $<0.9$

Table 4.2 HTMT discriminant validity testing

\begin{tabular}{|l|l|l|l|l|l|}
\hline & X1 & Y1 & Y2 & Y3 & Y5 \\
\hline X1 & & & & & \\
\hline Y1 & 0.679 & & & & \\
\hline Y2 & 0.063 & 0.734 & & & \\
\hline Y3 & 0.626 & 0.618 & 0.304 & & \\
\hline Y5 & 0.136 & 0.495 & 0.715 & 0.301 & \\
\hline
\end{tabular}

Table 4.3 Correlation analysis of HTMT discriminant validity

\begin{tabular}{|l|r|r|r|r|r|r|r|r|}
\hline & \multicolumn{1}{|c|}{ 1234 } & \multicolumn{1}{l|}{ A78 } & \multicolumn{1}{l}{ B1 } & \multicolumn{1}{l}{ B3 } & \multicolumn{1}{l}{ B5 } & \multicolumn{1}{l}{ C2 } & \multicolumn{1}{l}{ D1 } & \multicolumn{1}{l|}{ D3 } \\
\hline A1234 & 1.000 & 0.846 & 0.643 & -0.041 & -0.638 & -0.040 & -0.088 & 0.079 \\
\hline A78 & 0.846 & 1.000 & 0.606 & -0.060 & -0.514 & -0.087 & 0.089 & 0.141 \\
\hline B1 & 0.643 & 0.606 & 1.000 & -0.730 & -0.618 & -0.731 & -0.312 & -0.471 \\
\hline B3 & -0.041 & -0.060 & -0.730 & 1.000 & 0.317 & 0.989 & 0.378 & 0.759 \\
\hline B5 & -0.638 & -0.514 & -0.618 & 0.317 & 1.000 & 0.287 & 0.207 & 0.270 \\
\hline C2 & -0.040 & -0.087 & -0.731 & 0.989 & 0.287 & 1.000 & 0.347 & 0.766 \\
\hline D1 & -0.088 & 0.089 & -0.312 & 0.378 & 0.207 & 0.347 & 1.000 & 0.626 \\
\hline D3 & 0.079 & 0.141 & -0.471 & 0.759 & 0.270 & 0.766 & 0.626 & 1.000 \\
\hline
\end{tabular}

there is an HTMT value between Y2 \& Y4 of 0.989> 0.9, then Y2 and Y4 are not valid in discriminant validity. This is usually influenced by a very strong correlation between the two latent variables, and the strong correlation is caused by a strong correlation between indicators of the two latent variables. Then both latent variables should be combined into one latent variable. The multicollinearity validation test uses the Varian inflating factor (VIF) value $<10$.

Table 4.4 VIF multicolinearity validation testing

\begin{tabular}{|l|r|}
\hline & VIF \\
\hline A1234 & 3.524 \\
\hline A78 & 3.524 \\
\hline B1 & 1.000 \\
\hline B3 & $\mathbf{4 7 . 3 6 0}$ \\
\hline B5 & 1.000 \\
\hline C2 & $\mathbf{4 7 . 3 6 0}$ \\
\hline D1 & 1.646 \\
\hline D3 & 1.646 \\
\hline
\end{tabular}

Table 4.5 Correlation analysis of VIF multicollinearity validation

\begin{tabular}{|l|r|r|r|r|r|r|r|r|r|}
\hline & A1234 & \multicolumn{1}{|l}{ A78 } & B1 & \multicolumn{1}{l}{ B3 } & \multicolumn{1}{l|}{ B5 } & \multicolumn{1}{l|}{ C2 } & \multicolumn{1}{l}{ D1 } & D3 \\
\hline A1234 & 1.000 & 0.846 & 0.643 & -0.041 & -0.638 & -0.040 & -0.088 & 0.079 \\
\hline A78 & 0.846 & 1.000 & 0.606 & -0.060 & -0.514 & -0.087 & 0.089 & 0.141 \\
\hline B1 & 0.643 & 0.606 & 1.000 & -0.730 & -0.618 & -0.731 & -0.312 & -0.471 \\
\hline B3 & -0.041 & -0.060 & -0.730 & 1.000 & 0.317 & 0.989 & 0.378 & 0.759 \\
\hline B5 & -0.638 & -0.514 & -0.618 & 0.317 & 1.000 & 0.287 & 0.207 & 0.270 \\
\hline C2 & -0.040 & -0.087 & -0.731 & 0.989 & 0.287 & 1.000 & 0.347 & 0.766 \\
\hline D1 & -0.088 & 0.089 & -0.312 & 0.378 & 0.207 & 0.347 & 1.000 & 0.626 \\
\hline D3 & 0.079 & 0.141 & -0.471 & 0.759 & 0.270 & 0.766 & 0.626 & 1.000 \\
\hline
\end{tabular}

there is a correlation between B3 and C2 with a value of 0.989> 0.9 , then the two are strongly correlated with each other which causes multicolinearity. the next step that must be done is to remove one of the two indicators.

- The reliability indicator has qualified with outer loading value $>0.7$

$$
\text { Table 4.6 final testing outer loading }
$$

\begin{tabular}{|l|l|l|l|l|l|}
\hline & X1 & Y1 & Y2 & Y3 & Y5 \\
\hline A1234 & 0.963 & & & & \\
\hline A78 & 0.958 & & & & \\
\hline B1 & & 1.000 & & & \\
\hline B3 & & & 1.000 & & \\
\hline B5 & & & & 1.000 & \\
\hline D1 & & & & & 0.822 \\
\hline D3 & & & & & 0.959 \\
\hline
\end{tabular}

4.2. Realibility construct analysis, convergent validity \& model undimencial testing

Contruct Reliability is a Test to measure the reliability of latent variable constructs. Construct reliability is equal to Chronbach alpha> 0.7

- The validity of convergence is determined based on the principle that the gauges of a construct should be highly correlated, measured by ave value $>0.5$

- Undimensionality testing of the model is intended to ensure that there are no problems with measurement. With indicator measure CR > 0.7 and Cronbach alpha > 0.7

Based on the table, the construct has been reliable, valid convergently and all constructs have qualified for the undimensionality test.

Table 4.7 Analysis of realibility construct testing, convergent validity and unidimensional model

\begin{tabular}{|l|r|r|r|r|}
\hline & \multicolumn{1}{|l|}{$\begin{array}{l}\text { Cronbach's } \\
\text { Alpha }\end{array}$} & \multicolumn{1}{|l|}{ rho_A } & $\begin{array}{l}\text { Composite } \\
\text { Reliability }\end{array}$ & $\begin{array}{l}\text { Average } \\
\text { Variance } \\
\text { Extracted (AVE) }\end{array}$ \\
\hline X1 & 0.917 & 0.919 & 0.960 & 0.923 \\
\hline Y1 & 1.000 & 1.000 & 1.000 & 1.000 \\
\hline Y2 & 1.000 & 1.000 & 1.000 & 1.000 \\
\hline Y3 & 1.000 & 1.000 & 1.000 & 1.000 \\
\hline Y5 & 0.770 & 1.047 & 0.887 & 0.797 \\
\hline
\end{tabular}

4.3. Analysis of Discriminant Validity Testing using Fornell-Larcker Criterion

A construct is declared valid by comparing the root value of the AVE (Fornell-Larcker Criterion) with the correlation value between latent variables. AVE root> correlation value between variables. 
Table 4.8 Fornell-Larcker Criterion discriminant validity testing

\begin{tabular}{|l|r|r|r|r|r|}
\hline & \multicolumn{1}{|l|}{ X1 } & \multicolumn{1}{|l|}{ Y1 } & \multicolumn{1}{l|}{ Y2 } & \multicolumn{1}{l|}{ Y3 } & \multicolumn{1}{l|}{ Y5 } \\
\hline X1 & 0.961 & & & & \\
\hline Y1 & 0.651 & 1.000 & & & \\
\hline Y2 & -0.053 & -0.730 & 1.000 & & \\
\hline Y3 & -0.601 & -0.618 & 0.317 & 1.000 & \\
\hline Y5 & 0.082 & -0.458 & 0.693 & 0.273 & 0.893 \\
\hline
\end{tabular}

Based on the table 4.8 , the root AVE value> of all correlation values between latency variables, it has met the requirements of the discriminant validity test using the Forneel-Larckell criterion.

\subsection{Discriminant validity test analysis using cross- loading value}

Cross-loading is another method of finding discriminant validity. The expected cross loading value is $>0.7$

Table 4.9 Testing the discriminant validity using the cross

\begin{tabular}{|c|c|c|c|c|c|}
\hline \multicolumn{6}{|c|}{ loading value } \\
\hline & $\mathbf{X 1}$ & Y1 & Y2 & Y3 & Y5 \\
\hline $\mathbf{A 1 2 3 4}$ & 0.963 & 0.643 & -0.041 & -0.638 & 0.026 \\
\hline $\mathbf{A 7 8}$ & 0.958 & 0.606 & -0.060 & -0.514 & 0.136 \\
\hline B1 & 0.651 & 1.000 & -0.730 & -0.618 & -0.458 \\
\hline B3 & -0.053 & -0.730 & 1.000 & 0.317 & 0.693 \\
\hline B5 & -0.601 & -0.618 & 0.317 & 1.000 & 0.273 \\
\hline D1 & -0.002 & -0.312 & 0.378 & 0.207 & 0.822 \\
\hline D3 & 0.114 & -0.471 & 0.759 & 0.270 & 0.959 \\
\hline
\end{tabular}

From the table above 4.9 it can be seen that all loading indicators on the construct $>$ cross loading, it can be stated that this model has met the requirements of discriminant validity.

\subsection{Multicollinearity test analysis reflective model}

The formative multicollinearity test has met the requirements, based on the VIF value table $<5$

Table 4.10 Fornell-Larcker Criterion discriminant validity testing

\begin{tabular}{|l|r|}
\hline & \multicolumn{1}{|l|}{ VIF } \\
\hline A1234 & 3.524 \\
\hline A78 & 3.524 \\
\hline B1 & $\mathbf{1 . 0 0 0}$ \\
\hline B3 & $\mathbf{1 . 0 0 0}$ \\
\hline B5 & $\mathbf{1 . 0 0 0}$ \\
\hline D1 & $\mathbf{1 . 6 4 6}$ \\
\hline D3 & $\mathbf{1 . 6 4 6}$ \\
\hline
\end{tabular}

It is concluded that in testing the outer reflective model carried out in this model, all items or indicators have met the validity and reliability requirements and there is no multicollinearity between the 20 indicators.

\subsection{Interpretation of results (Inner model)}

4.6.1. Total effect testing analysis

This test is used to see the magnitude of the direct effect of each independent (exogenous) variable on the dependent variable (endogenous).

Table 4.11 Total Effect testing analysis

\begin{tabular}{|l|r|r|r|r|r|}
\hline & $\begin{array}{l}\text { Original } \\
\text { Sample (O) }\end{array}$ & $\begin{array}{l}\text { Sample } \\
\text { Mean (M) }\end{array}$ & $\begin{array}{l}\text { Standard } \\
\text { Deviation } \\
\text { (STDEV) }\end{array}$ & $\begin{array}{l}\text { T Statistics } \\
\text { (|O/STDEV|) }\end{array}$ & $\begin{array}{l}\text { P } \\
\text { Values }\end{array}$ \\
\hline $\mathbf{X 1 ~ - > ~ Y 1 ~}$ & 0.651 & 0.680 & 0.133 & 4.904 & 0.000 \\
\hline $\mathbf{X 1 ~ - > ~ Y 2 ~}$ & -0.475 & -0.496 & 0.128 & 3.710 & 0.000 \\
\hline $\mathbf{X 1}$-> Y3 & -0.150 & -0.167 & 0.117 & 1.288 & 0.198 \\
\hline $\mathbf{X 1 ~ - > ~ Y 5 ~}$ & -0.329 & -0.345 & 0.149 & 2.208 & 0.028 \\
\hline Y1 -> Y2 & -0.730 & -0.741 & 0.152 & 4.806 & 0.000 \\
\hline Y1 -> Y3 & -0.231 & -0.253 & 0.170 & 1.358 & 0.175 \\
\hline Y1 -> Y5 & -0.506 & -0.518 & 0.200 & 2.533 & 0.012 \\
\hline Y2 -> Y3 & 0.317 & 0.322 & 0.198 & 1.598 & 0.111 \\
\hline Y2 -> Y5 & 0.693 & 0.700 & 0.223 & 3.099 & 0.002 \\
\hline
\end{tabular}

Overall, the significance of the effect of each item on its construct and the effect of each independent variable partially on the dependent variable is as follows

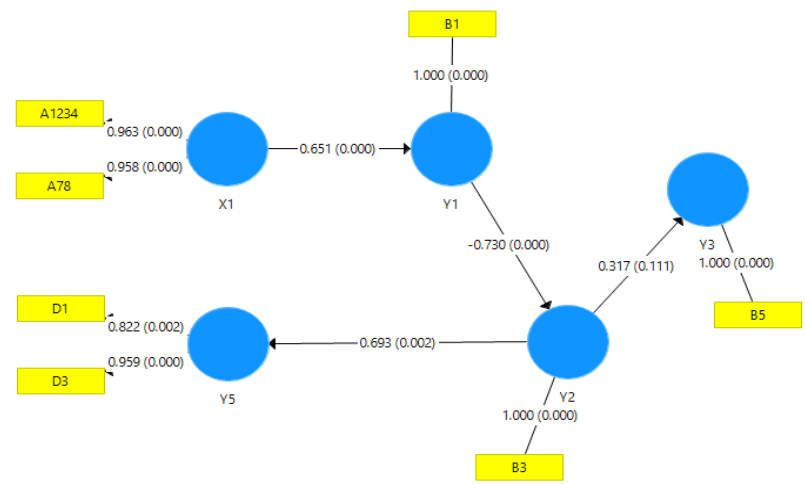

Figure 4.1 Results Analysis of variable correlation significance

\subsubsection{Testing analysis using the $\mathbf{R}$-Square value} (goodness-fit-model)

The values of $\mathrm{R} 2=0.75, \mathrm{R} 2=0.50$, and $\mathrm{R} 2=0.25$ indicate that the model is strong, moderate, and weak

Table 4.12 Goodness-fit-model test analysis

\begin{tabular}{|l|r|r|}
\hline & \multicolumn{1}{|l|}{$\begin{array}{l}\text { R } \\
\text { Square }\end{array}$} & \multicolumn{1}{l|}{$\begin{array}{l}\text { R Square } \\
\text { Adjusted }\end{array}$} \\
\hline Y1 & 0.423 & 0.366 \\
\hline Y2 & 0.533 & 0.486 \\
\hline Y3 & 0.100 & 0.010 \\
\hline Y5 & 0.480 & 0.428 \\
\hline
\end{tabular}

It can be concluded that, all independent variables on the dependent variable are weak.

\subsubsection{Test analysis using the F-Square (Effect Size) value}

Tests using the F-Square value, are used to assess the magnitude of the influence between variables using the Effect Size or fsquare, in addition to validating the presence or absence of a significant relationship between variables.

Table 4.13 Analysis of the Effect Size test results 


\begin{tabular}{|c|c|c|c|c|c|}
\hline & $\mathrm{X1}$ & Y1 & Y2 & Y3 & \begin{tabular}{|l} 
Y5 \\
\end{tabular} \\
\hline $\mathrm{X} 1$ & & 0.734 & & & \\
\hline Y1 & & & 1.142 & & \\
\hline Y2 & & & & 0.111 & 0.922 \\
\hline$\overline{\mathrm{Y3}}$ & & & & & \\
\hline $\begin{array}{l}55 \\
\end{array}$ & & & & & \\
\hline
\end{tabular}

based on the table, the F Square value above can be stated:

- $\quad$ The effect of large size is the effect of X1 on Y1, Y1 on $\mathrm{Y} 2$ and $\mathrm{Y} 2$ on Y5. Because it has an F-Square value> 0.35

- $\quad$ The effect of Y2 on Y3 is one that has a moderate effect, because it has an Effect size (F-Square) in the range 0.15

\subsubsection{Test Analysis using Relevance Prediction (Q-Square)}

The relevance of prediction is the analysis test to assess whether the prediction obtained is of relevance or not. Q Square> 0 indicates that the model has an accurate predictive relevance for a particular construct, while the value of Q Square $<0$ indicates that the model lacks predictive relevance. It can be concluded that the relevance of the predictions for Y1, Y2, Y3 and Y5 is relevant or accurate.

Table 4.14 Analysis of the results of the Prediction Relevance test

\begin{tabular}{|l|r|r|r|}
\hline & \multicolumn{1}{|c|}{ SSO } & SSE & $\mathbf{Q}^{2}$ (=1-SSE/SSO) \\
\hline X1 & 24.000 & 24.000 & \\
\hline Y1 & 12.000 & 8.418 & 0.299 \\
\hline Y2 & 12.000 & 6.838 & 0.430 \\
\hline Y3 & 12.000 & 11.187 & 0.068 \\
\hline Y5 & 24.000 & 19.117 & 0.203 \\
\hline
\end{tabular}

4.6.5.

Inner Model Multicollinearity Testing

The formative multicollinearity test has met the requirements, based on the VIF value table $<5$

Table 4.15 Analysis of the multicollinearity inner model test

\begin{tabular}{|l|l|l|l|l|l|}
\hline & $\mathbf{X} 1$ & Y1 & Y2 & Y3 & Y5 \\
\hline X1 & & 1.000 & & & \\
\hline Y1 & & & 1.000 & & \\
\hline Y2 & & & & 1.000 & 1.000 \\
\hline Y3 & & & & & \\
\hline Y5 & & & & & \\
\hline
\end{tabular}

then the model can be stated that there is no multicollinearity problem. This fact is supported by the absence of a strong correlation between independent variables as in the following table:

Table 4.16 Correlation between variables in the inner model multicollinearity

\begin{tabular}{|c|c|c|c|c|c|}
\hline \multirow{2}{*}{\multicolumn{6}{|c|}{ Y2 }} \\
\hline & & & & & \\
\hline $\mathbf{X 1}$ & 1.000 & 0.651 & -0.053 & -0.601 & 0.082 \\
\hline Y1 & 0.651 & 1.000 & -0.730 & -0.618 & -0.458 \\
\hline Y2 & -0.053 & -0.730 & 1.000 & 0.317 & 0.693 \\
\hline Y3 & -0.601 & -0.618 & 0.317 & 1.000 & 0.273 \\
\hline Y5 & 0.082 & -0.458 & 0.693 & 0.273 & 1.000 \\
\hline
\end{tabular}

The table above shows that there is no strong correlation between independent variables, a strong variable is stated if the correlation value of each variable is $(>0.9$ or $<-0.9)$.

\subsubsection{Model Fit Testing}

the limitations or criteria for the fit model include:

- RMS Theta value or Root Mean Square Theta $<0.102$,

- The value of SRMR or Standardized Root Mean Square $<0.10$ or $<0.08$

- $\quad$ and NFI Value $>0.9$.

The following are the results of the analysis on the Fit Model test:

Table 4.17 Pengujian model fit

\begin{tabular}{|l|r|r|} 
& \multicolumn{1}{|l|}{$\begin{array}{l}\text { Saturated } \\
\text { Model }\end{array}$} & \multicolumn{1}{l|}{$\begin{array}{l}\text { Estimated } \\
\text { Model }\end{array}$} \\
\hline SRMR & 0.065 & 0.227 \\
\hline d_ULS & 0.120 & 1.447 \\
\hline d_G1 & 0.271 & 0.914 \\
\hline d_G2 & 0.157 & 0.608 \\
\hline Chi-Square & 11.165 & 29.533 \\
\hline NFI & 0.834 & 0.560 \\
\hline
\end{tabular}

rms Theta
\begin{tabular}{|l|r|}
\hline & \\
\hline rms Theta & 0.418 \\
\hline
\end{tabular}

From the tests carried out the analysis results obtained:

- RMS Theta value or Root Mean Square Theta 0.418> 0.102

- $\quad$ and NFI $0.834<0.9$, then the model does not fit the data.

- However, the SRMR or Standardized Root Mean Square value is $0.065<0.10$, so based on the SRMR assessment, the model meets the criteria for the fit model.

So that in the model testing carried out, it can be concluded that the model is fit with the data.

\subsection{Evaluation of Measurement formative Model (Outer} Model)

In testing, the valid requirement for the outer loading value on each indicator is $>0.7$, but the Outer Loading value limit>0.5 is still acceptable, provided that the construct validity and reliability meet the requirements. While indicators C1, B2 and D1 because the outer loading is $<0.6$.

Table 4.18 testing the formative outer loading model

\begin{tabular}{|l|l|l|l|l|l|l|}
\hline & X1 & Y1 & Y2 & Y3 & Y4 & Y5 \\
\hline A1234 & 0.646 & & & & & \\
\hline A56 & 0.680 & & & & & \\
\hline A78 & 0.610 & & & & & \\
\hline B1 & & 1.000 & & & & \\
\hline B3 & & & 1.000 & & & \\
\hline B5 & & & & 1.000 & & \\
\hline C2 & & & & & 1.000 & \\
\hline D3 & & & & & & 1.000 \\
\hline
\end{tabular}

- The multicollinearity validation test used the variance value of the inflating factor (VIF) $<5$

Table 4.19 Multicollinearity analysis based on VIF

\begin{tabular}{|l|r|}
\hline \multicolumn{2}{|c|}{ assessment } \\
\hline A1234 & VIF \\
\hline A56 & 3.731 \\
\hline A78 & 1.059 \\
\hline B1 & 3.678 \\
\hline B3 & 1.000 \\
\hline B5 & 1.000 \\
\hline D3 & 1.000 \\
\hline
\end{tabular}


In testing the VIF value $<5$, it meets the requirements, but on the $\mathrm{C} 2$ and $\mathrm{B} 3$ indicators there is multicollinearity (VIF) $>5$, so the correlation between indicators is strong, so that $\mathrm{C} 2$ can be removed from the model.

\subsubsection{Analysis of significance and relevance of} indicators to latent variables

Based on the table, the $\mathrm{P}$ value of all indicators is $<0.05$, so accept $\mathrm{H} 1$ which means that all $\mathrm{X} 1$ indicators significantly affect $\mathrm{X} 1$, so the $\mathrm{X} 1$ indicator is relevance as an indicator of the latent variable $\mathrm{X} 1$. It is concluded that all items or indicators have met the requirements of convergent validity, non-multicollinearity and there is no multicollinearity between indicators.

Table 4.20 Analyze the significance and relevance of indicators to latent variables

\begin{tabular}{|l|r|r|r|r|r|}
\hline & $\begin{array}{l}\text { Original } \\
\text { Sample } \\
\text { (O) }\end{array}$ & Sample Mean (M) & $\begin{array}{l}\text { Standard } \\
\text { Deviation } \\
\text { (STDEV) }\end{array}$ & $\begin{array}{l}\text { T Statistics } \\
\text { (|O/STDEV|) }\end{array}$ & $\begin{array}{l}\text { P } \\
\text { Values }\end{array}$ \\
\hline A1234 > X1 & 0.646 & 0.645 & 0.183 & 3.529 & 0.000 \\
\hline A56 $>$ X1 & 0.680 & 0.664 & 0.266 & 2.557 & 0.011 \\
\hline A78 $>$ X1 & 0.610 & 0.575 & 0.202 & 3.017 & 0.003 \\
\hline B1 $>$ Y1 & 1.000 & 1.000 & 0.000 & & \\
\hline B3 $>$ Y2 & 1.000 & 1.000 & 0.000 & & \\
\hline B5 $>$ Y3 & 1.000 & 1.000 & 0.000 & & \\
\hline D3 $>$ Y5 & 1.000 & 1.000 & 0.000 & & \\
\hline
\end{tabular}

\subsection{Interpretation of the results (Inner model) Formative}

The results of the inner model formative analysis with Bootstrapping ( $\mathrm{T}$ Value) are as follows :

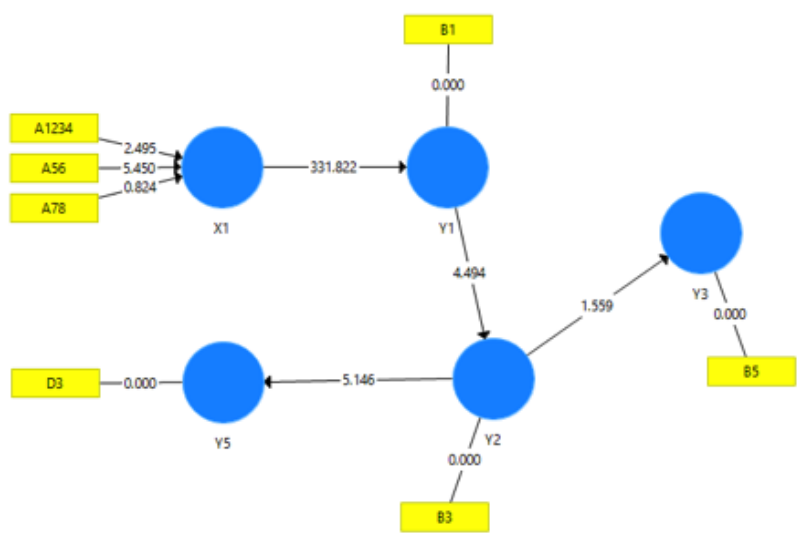

Figure 4.2 Results of the Inner Model Analysis with Bootstrapping (TValue)

4.8.1. Total effect testing analysis
Table 4.21 Total Effect test analysis for the inner formative model

\begin{tabular}{|c|c|c|c|c|c|}
\hline & $\begin{array}{l}\text { Original } \\
\text { Sample (0) }\end{array}$ & $\begin{array}{l}\text { Sample } \\
\text { Mean (M) }\end{array}$ & $\begin{array}{l}\text { Standard } \\
\text { Deviation } \\
\text { (STDEV) } \\
\end{array}$ & $\begin{array}{l}\text { T Statistics } \\
\text { (|O/STDEV|) }\end{array}$ & P Values \\
\hline $\mathrm{X} 1>\mathrm{Y1}$ & 0.995 & 0.996 & 0.003 & 331.822 & 0.000 \\
\hline $\mathrm{X} 1 \mathrm{P}$ Y2 & -0.726 & -0.730 & 0.162 & 4.485 & 0.000 \\
\hline $\mathrm{X} 1 \rightarrow \mathrm{Y} 3$ & -0.230 & -0.253 & 0.172 & 1.336 & 0.182 \\
\hline $\mathrm{X} 1$-> Y5 & -0.551 & -0.552 & 0.172 & 3.215 & 0.001 \\
\hline Y1 -> Y2 & -0.730 & -0.732 & 0.162 & 4.494 & 0.000 \\
\hline $\mathrm{Y1}$-> Y3 & -0.231 & -0.254 & 0.173 & 1.340 & 0.181 \\
\hline Y1 -> Y5 & -0.554 & -0.554 & 0.172 & 3.224 & 0.001 \\
\hline Y2 $>$ Y3 & 0.317 & 0.323 & 0.203 & 1.559 & 0.120 \\
\hline Y2 $>$ Y5 & 0.759 & 0.754 & 0.148 & 5.146 & 0.000 \\
\hline
\end{tabular}

From the test, all significant total effects or acceptance of $\mathrm{H} 1$ are those that have $\mathrm{p}$ value $<0.05$, and those that are not significant or accept $\mathrm{H} 0$, namely the total effect of $\mathrm{X} 1$ on $\mathrm{Y} 3, \mathrm{Y} 1$ on $\mathrm{Y} 3$ and Y2 on Y3.

4.8.2. Testing analysis using the R-Square value (goodness-fit-model)

In testing it is concluded that, the effect of the independent variable $\mathrm{X} 1$ on the dependent variable $(\mathrm{Y} 1)$, and the variable $\mathrm{Y} 3$ on $\mathrm{Y} 5$ is strong. Meanwhile, all independent variables $\mathrm{Y} 1$ to variable $\mathrm{Y} 2$, and $\mathrm{Y} 2$ to $\mathrm{Y} 3$ are bound to be weak.

Figure 4.22 Goodness-fit-model inner model test analysis formatif

\begin{tabular}{|l|r|r|}
\hline & \multicolumn{1}{|c|}{ R Square } & \multicolumn{1}{|l|}{$\begin{array}{l}\text { R Square } \\
\text { Adjusted }\end{array}$} \\
\hline Y1 & 0.989 & 0.988 \\
\hline Y2 & 0.533 & 0.486 \\
\hline Y3 & 0.100 & 0.010 \\
\hline Y5 & 0.577 & 0.534 \\
\hline
\end{tabular}

\subsubsection{Test analysis using the F-Square (Effect} Size) value

Table 4.12 Analysis of the formative model inner effect size test

\begin{tabular}{|l|l|l|l|l|l|}
\hline & X1 & Y1 & Y2 & Y3 & Y5 \\
\hline X1 & & 91.497 & & & \\
\hline Y1 & & & 1.142 & & \\
\hline Y2 & & & & 0.111 & 1.362 \\
\hline Y3 & & & & & \\
\hline Y5 & & & & & \\
\hline
\end{tabular}

based on the table, the F Square value above can be stated:

- The effect of large size is the effect of X1 on Y1, Y1 on $\mathrm{Y} 2$ and $\mathrm{Y} 2$ on Y5. Because it has an F-Square value> 0.35

- Meanwhile, the effect of Y2 on Y3 is moderate. Because it has an Effect size (F-Square) in the range 0.15

\subsubsection{Test Analysis using Relevance Prediction} (Q-Square)

based on the table, the value of Q Square above, it is concluded that the prediction of $\mathrm{Y} 1, \mathrm{Y} 2, \mathrm{Y} 3$ and $\mathrm{Y} 5$ is relevant or accurate because it has a value of Q Square> 0.05 .

Table 4.23 Analysis of testing the prediction relevance of inner formative models 


\begin{tabular}{|l|r|l|l|l|}
\hline & \multicolumn{1}{|l|}{ SSO } & SSE & \multicolumn{2}{l|}{$\mathbf{Q}^{\mathbf{2}}$ (=1-SSE/SSO) } \\
\hline X1 & 36.000 & n/a & n/a & 0.707 \\
\hline Y1 & 12.000 & 3.517 & \\
\hline Y2 & 12.000 & 6.838 & 0.430 \\
\hline Y3 & 12.000 & 11.187 & & 0.068 \\
\hline Y5 & 12.000 & 6.593 & & 0.451 \\
\hline
\end{tabular}

4.8.5. Inner Model Multicollinearity Testing

Based on the table, the VIF value does not have a VIF value $<5$, so the model can be stated that there is no multicollinearity problem.

Tabel 4.24 Multicollinearity inner model test analysis

\begin{tabular}{|l|l|l|l|l|l|}
\hline & $\mathbf{X 1}$ & Y1 & Y2 & Y3 & Y5 \\
\hline X1 & & 1.000 & & & \\
\hline Y1 & & & 1.000 & & \\
\hline Y2 & & & & 1.000 & 1.000 \\
\hline Y3 & & & & & \\
\hline Y5 & & & & & \\
\hline
\end{tabular}

\section{Uji Hipotesa}

The hypothesis test in this study was conducted by looking at TStatistics values and P-Values values. The research hypothesis can be accepted if the P-Values value $<0.05$. it can be concluded that of the 5 (five) hypotheses proposed in this study, all are acceptable because each of the influences shown has a P-Values value $<0.05$. Except the hypothesis testing H3 (influence energy cost total production, against potential cost saving profitability Co-Generation power plant). So it can be stated that 4 independent variables to its dependencies have a significant influence, namely:

1. The value of OPE (X1) consisting of 3 (Three) components of Eight major losses has a significant positive effect on performance (Y1), where:

$Y 1=0.995 X 1$

2. Productivity boiler production performance (Y1) with indicator B1, very significantly negative effect on Energy Cost total production (Y2), where :

$Y 2=-0.730 Y 1$

3. The amount of production cost of Energy cost total / Energy cost total consumption (Y2) with indicator B3 is very significant positive effect on energy cost total pulp \&paper manufacturing production (Y5) with indicator D3, where :

$Y 5=0.759 Y^{2}$

4. To increase profitability and performance can be done by increasing the value of OPE (X1) or lowering Eight Major losses or 8 major losses (A1234, A56 \&A78). And from the results of SEM-PLS in figure 4.25, the influence of each OPE constituent indicator is :

$\mathrm{X} 1=0,803(\mathrm{~A} 1234)+0,776(\mathrm{~A} 56)-0,076(\mathrm{~A} 78)$

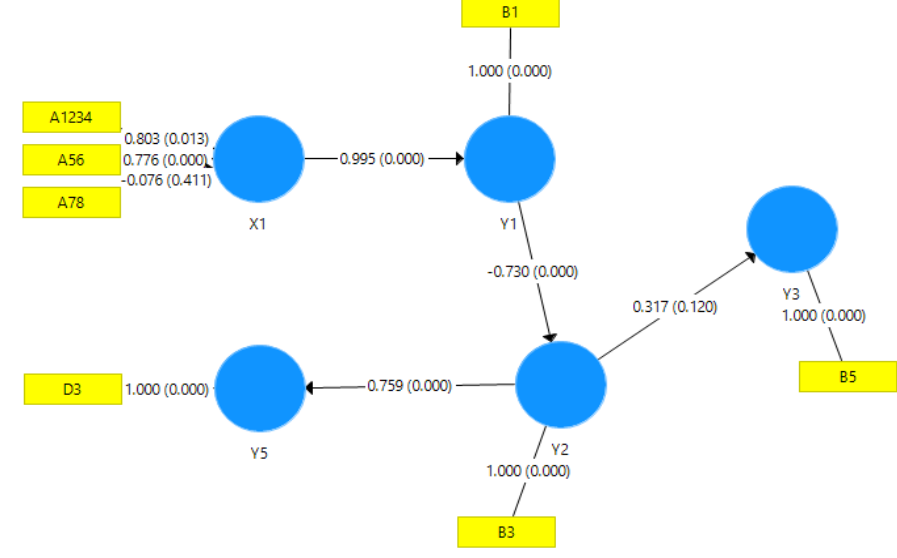

Figure 5.1 Final result Analysis of the influence of correlation between variables

6. Conclusions

To provide potential benefits for pulp and paper mills manufacturing PT. XYZ, the priority improvement that must be done to eliminate eight major losses on boiler machines in the cogeneration plant is to fix four (6) availability indicators (A1234) and Performance (A56) namely elimination shutdown loss (A1), production adjustment loss (A2), Equipment failure loss (A3), Process failure loss (A4), Normal Production loss (A5), and Abnormal Production loss (A6).

Then, to provide potential saving to Pulp \&paper mills manufacturing, Energy Price can be reduced by increasing productivity by reducing downtime losses caused by engine failure and improving the performance or speed of the production process.

\section{Daftar Pustaka}

ANALISIS INDUSTRI PULP DAN KERTAS DUNIA: Masukan bagi Pengelola BUMN Biro Riset LM FEUI Kendati praktek pekerjaan. (2009). 1-15.

Bierer, A., \& Götze, U. (2012). Energy Cost Accounting: Conventional and Flow-oriented Approaches. Journal of Competitiveness, 4(2), 128-144. https://doi.org/10.7441/joc.2012.02.09

Gambini, M., Vellini, M., Stilo, T., Manno, M., \& Bellocchi, S. (2019). High-efficiency cogeneration systems: The case of the paper industry in Italy. Energies, 12(3). https://doi.org/10.3390/en12030335

Hair, J. F., Sarstedt, M., Hopkins, L., \& Kuppelwieser, V. G. (2014). Partial least squares structural equation modeling (PLSSEM): An emerging tool in business research. European Business Review, 26(2), 106-121. https://doi.org/10.1108/EBR-10-20130128

Leguina, A. (2015). A primer on partial least squares structural equation modeling (PLS-SEM). International Journal of Research \& Method in Education, 38(2), 220-221. https://doi.org/10.1080/1743727x.2015.1005806 
Mardono, U., Rimawan, E., Pratondo, T., \& Saraswati, I. (2019). An analysis of the effect of elimination of six big losses on increasing profitability in steel rolling mill companies. International Journal of Mechanical and Production Engineering Research and Development, 9(2), 387-398. https://doi.org/10.24247/ijmperdapr201937

Nayak, D. M., Naidu, G. S., Shankar, V., Manager, A., \& Manager, A. (2013). Evaluation Of OEE In A Continuous Process Industry On An Insulation Line In A Cable Manufacturing Unit. International Journal of Innovative Research in Science, Engineering and Technology, 2(5), 1629-1634.

Pusdatin Kemenperin. (2019). Analisis perkembangan industri. In Kementerian Perindustrian RI (pp. 12-13).

Putra, G. P., \& Purba, H. H. (2018). Failure mode and effect aanalysis on power plant boiler. In Journal of Optimization in Industrial Engineering (Vol. 11, Issue 2, pp. 1-5). https://doi.org/10.22094/JOIE.2018.555547.1527

Shabbir, I., \& Mirzaeian, M. (2016). Feasibility analysis of different cogeneration systems for a paper mill to improve its energy efficiency. International Journal of Hydrogen Energy, 41(37), 16535-16548. https://doi.org/10.1016/j.ijhydene.2016.05.215

Shabbir, I., Mirzaeian, M., Mooney, J., \& Anvari, F. (2016). Energy efficiency improvement potentials of pulp and paper sector through energy benchmarking and cogeneration. ECOS 2016 - Proceedings of the 29th International Conference on Efficiency, Cost, Optimisation, Simulation and Environmental Impact of Energy Systems.

Singgih, S. (2006). Menguasai Statistik Di Era Informasi Dengan SPSS 15. Elex Media Komputindo.

Sugiyono, A. (2015). Penggunaan Energi di Industri Pulp dan Kertas : Aspek Teknologi dan Lingkungan. December 2009.

Suzuki, T., Ed. (1994). TPM in Process Industries. Portland, OR, Productivity Press 